\title{
NOBILING, Oskar. As cantigas de D. Joan Garcia de Guilhade e Estudos Dispersos. Yara Frateschi Vieira (Org., Intr. e Notas). Niteroi: EdUFF, 2007, 488 p. Coleção Medieval, 2.
}

Rafael Teixeira de Paula Lima Universidade Federal de Minas Gerais

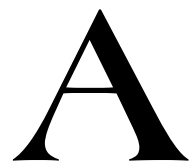

coleção Estante Medieval, da EdUFF, através do minucioso trabalho da professora Yara Frateschi Vieira, presenteia os interessados pelos estudos filológicos com a publicação de As cantigas de D. Joan Garcia de Guilhade e estudos dispersos. A edição - composta por estudos do renomado lusitanista Oskar Nobiling, reconhecido sempre pela profundidade, e colocado ao lado de nomes de importância na área filológica como Henry Lang e Carolina Michaëlis de Vasconcelos - enriquece o catálogo de publicações da Editora da Universidade Federal Fluminense. A publicação recebe uma apresentação sucinta, porém abrangente do professor, gramático e filólogo
Evanildo Bechara, membro da Academia Brasileira de Letras e de Filologia.

As cantigas de D. Joan Garcia de Guilhade e estudos dispersos apresentase, pois, como uma edição fundamental para os leitores interessados na literatura da Idade Média, historiografia, filologia e linguística. Além da reconhecida tese defendida na Universidade de Bonn, em 1907 - uma edição crítica das cantigas do trovador galego-português Joan Garcia de Guilhade - o volume apresenta uma recolha feita pela professora Yara Frateschi Vieira de trabalhos dispersos de Nobiling, de modo a tornar a edição ainda mais rica. Uma pequena, porém seleta e acurada bibliografia complementa o volume, que, junta- 
mente com um caderno fotográfico e um apêndice composto por correspondências trocadas entre Oskar Nobiling e o filólogo português José Leite de Vasconcelos, possibilita ao leitor um aprofundamento no trabalho do pesquisador alemão.

É digno de nota o precioso trabalho de tradução e compilação da professora Yara Frateschi Vieira, assim como seu empenho na tentativa de trazer aos leitores brasileiros ediçōes voltadas à temática medieval. Pesquisadora fecunda, além de uma produção vasta de livros, artigos e capítulos de livros, em 2004 ofereceu aos medievalistas e filólogos lusófonos o volume de referência Glosas Marginais ao Cancioneiro Medieval Português de Carolina Michaëlis de Vasconcelos, editado com o apoio das Universidades de Santiago de Compostela, de Coimbra e Unicamp. A presente publicação sobre Oskar Nobiling, bem como a sua edição das cantigas de Guilhade, e dos vários trabalhos dispersos desse autor, não fogem ao padrão criterioso, no qual toda publicação da professora se fundamenta. A introdução do livro, a cargo da pesquisadora, é um exemplo de diligência, oferecendo ao leitor um panorama, amplo e profundo, sobre a vida e percurso intelectual de Nobiling.
O livro é disposto em três blocos temáticos que, juntos, oferecem ao leitor uma perspectiva do trabalho do lusitanista em questão: Lírica Medieval Galego-Portuguesa, Lingua Portuguesa e Literatura Popular. O primeiro bloco apresenta um conjunto de seis textos do pesquisador alemão, sendo um deles a reconhecida tese doutoral defendida em Bonn, no âmbito da Ecdótica - uma edição crítica das cantigas de D. Joan Garcia de Guilhade - estudo que dá título ao livro.

D. Joan Garcia de Guilhade foi um cavaleiro português, natural de Guilhade, e esteve a serviço da poderosa linhagem dos Sousa, tendo vivido na corte do rei Afonso III, de Portugal. Participou, também, da corte castelhana de Fernando III, entre 1240 e 1247 , onde manteve relações literárias com Johan Soarez Coelho e o jogral Lourenço. É sabido que se relacionou com Pedr' Amigo de Sevilha e com Roi Queimado, na corte de Afonso X, o Sábio. As pesquisas da equipe de investigação da lírica profana galego-portuguesa, coordenada por Mercedes Brea, no Centro de Estudos Ramon Piñero, apontam para a última referência documental do trovador em 1270 , em um testamento, no qual aparece como testemunha. D. Joan Garcia 
de Guilhade se apresenta como peça fundamental nos estudos da literatura medieval, possuindo uma das mais extensas produções catalogadas. A tese doutoral de Oskar Nobiling cumpre, dessa forma, um papel fundamental para os medievalistas e estudiosos da literatura ibérica, do período em questão. Ainda no que diz respeito à literatura medieval galegoportuguesa, a edição compilada pela professora Yara Frateschi Vieira apresenta a resenha feita por Oskar Nobiling do livro Textos Archaicos, de José Leite de Vasconcelos, texto basilar para o estudo da filologia portuguesa, editado pela primeira vez na Revista Lusitana.

A seleta dos dispersos relacionados à Língua Portuguesa são materiais preciosos para os que se debruçam sobre esse campo de estudo. Citem-se como exemplos um estudo fonético, no qual Nobiling faz uma análise do uso das vogais nasais, no falar culto da capital federal à época e do interior brasileiros, relacionando-os com o português de Portugal (As vogais nasais em Português), além do notável estudo Albanês e Português, de caráter comparativo. Nele, Oskar Nobiling, trabalhando exaustiva-mente o vocabulário, problematiza, por exemplo, elementos formativos que o latim passou a todas as línguas românicas, fatores morfológicos comuns às línguas albanesa e portuguesa e, interessantemente, palavras que se encontram exclusivamente nas duas línguas dispostas como material de estudo. Complementando, o texto Brasileirismos e Crioulismos apresenta considerações dignas de nota no que diz respeito à sintaxe, apontando, por exemplo, a interessante inversão de locuções que os dialetos sofrem, além da hereditariedade dos traços gerais da evolução dos idiomas. Outro estudo de Nobiling contido no volume, Emendas $e$ Aditamentos à Seção Portuguesa do Lateinisch-Romanisches Wörterbuch de Körting, oferece ao estudioso da linguística românica uma ferramenta valiosa quando complementada com o Dicionário de Körting.

Fecha-se o livro com um florilégio de canções e quadras populares, seguidos por um estudo que problematiza o conceito de literatura oral e literatura popular. Nobiling utiliza exaustivamente material do crítico literário, ensaísta e estudioso do folclore nacional Sílvio Romero para sua coletânea de textos, provavelmente, uma edição de Cantos Populares do Brasil, editada em Lisboa. Além dessa rica recolha, vale citar o interessante Estudos sobre o Romanceiro Popular de Carolina Michaëlis de Vasconcelos, no qual Nobiling oferece 
considerações sobre a poesia dos romanceiros espanhóis.

O desafio de re-editar e de reunir numa só obra tão relevantes trabalhos para os estudos sobre o medievo, dispersos em revistas, não somente brasileiras como também européias foi aceito e vencido pela professora Yara Frateschi Vieira, trazendo ao público leitor brasileiro a rica possibilidade de observar toda a competência de um pesquisador dedicado ao estudo de nossa língua e seus monumentos literários. Cabe a nós aguardarmos que a Estante Medieval seja contemplada com mais edições do mesmo nível, criteriosamente selecionadas e cuidadosamente preparadas, com belíssima apresentação editorial. 